\title{
Estimation of Genetic Divergence and Gene Flow between Culex pipiens and Culex quinquefasciatus (Diptera: \\ Culicidae) in Argentina
}

Silvia G Humeres, Walter R Almirón*, Marta S Sabattini, Cristina N Gardenal/

Cátedra de Química Biológica, Facultad de Ciencias Médicas, cc.35, suc.16, 5016 Córdoba, Argentina *Centro de Investigaciones Entomológicas de Córdoba. Facultud de Ciencias Exactas, Físicas y Naturales, Universidad Nacional de Córdoba, Avda. Vélez Sársfield 299, 5000 Córdoba, Argentina

Allele frequencies at seven polymorphic loci controlling the synthesis of enzymes were analyzed in six populations of $\mathrm{Culex}$ pipiens $L$. and $\mathrm{Cx}$. quinquefasciatus Say. Sampling sites were situated along $a$ north-south line of about 2,000 km in Argentina. The predominant alleles at Mdh, Idh, Gpdh and $\mathrm{Gpi}$ loci presented similar frequencies in all the samples. Frequencies at the Pgm locus were similar for populations pairs sharing the same geographic area. The loci $\mathrm{Cat}$ and $\mathrm{Hk}-1$ presented significant geographic variation. The latter showed a marked latitudinal cline, with a frequency for allele $\mathrm{b}$ ranging from 0.99 in the northernmost point to 0.04 in the southernmost one, a pattern that may be explained by natural selection $\left(F_{S T}=0.46 ; p<0.0001\right)$ on heat sensitive alleles. The average value of $F_{S T}(0.088)$ and between genetic and geographic distance $(r=0.83 ; p<0.001)$. The highest genetic identity $\left(I_{N}=0.988\right)$ corresponded to the geographically closest samples from the central area. In one of these localities $\mathrm{Cx}$. quinquefasciatus was predominant and hybrid individuals were detected, while in the other, almost all the specimens were identified as $\mathrm{Cx}$. pipiens. To verify the fertility between $\mathrm{Cx}$. pipiens and $\mathrm{Cx}$. quinquefasciatus from the norhern- and sonhernmost populations, experimental crosses were perranged from 76.5 to $100 \%$. The hybrid progenies were fertile through two subsequent generations.

Key words: Culex pipiens - Culex quinquefasciatus - genetic divergence - gene flow - crossing experiments -

$$
\text { Argentina }
$$

Mosquitoes of the Culex pipiens L. Group are important vectors of St. Louis encephalitis (SLE) virus in the east-central United States and eastern Texas (Mitchell et al. 1980). A strain of SLE virus was isolated from $C x$. pipiens quinquefasciatus Say collected in Santa Fe Province, Argentina (Mitchell et al. 1985), and a colony established from the same site, showed to be an efficient vector of both the Argentine and United St The members of this

group are widely distributed throughout the world, with two predominant

This work was supported, in part, by the Consejo Nacional de Investigaciones Científicas y Técnicas (CONICET), Argentina, and the Consejo de Investigaciones Científicas y Tecnológicas de la Provincia de

COR CONICOR. species: Cx. pipiens and $C x$. quinquefasciatus. The ormer is restricted to cooler areas while the later inhabits warmer tropical and subtropical regions (Mattingly 1951, Laven 1967, Barr 1982). Morphological, ethological and ecological features

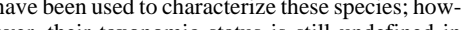
ever, their taxonomic status is still und some geophic areas.

Male genitalla morphology and morphometry (DV/D ratio) have been the main traits used to distinguish $C_{\text {. }}$. pipiens from $C_{x}$. quinquefasciatus. in North Ame (Sunder . Tabac 1976, Jowell 1983), nothern Jap, (Edwards 1921, Bekku 1956, Sar 1963. Ishii 1980), southeastern Australia (Dobrotworky 1967. Barr 1982), and the Middle East (Edwards 1921, Harbach 1985, 1988). In Africa the two 1921 , cur in sympatry but do not hybridize (Jupp 1978, cur in sympatry but do not hybridize (Jupp 1978, hybrid forms have been found in a central area of the country between $30^{\circ}$ and $33^{\circ} \mathrm{S}$ (Brewer or 1987, Almirón et al. 1995). 
Several authors have stressed the contribution of multilocus electrophoretic analysis to the knowledge of the genetic structure of populations of tries and to clarify their taxonomic position (Chen 1976, Tabachnick \& Powell 1983, Urbanelli et al. 1985, Villani et al. 1986). Studies of genetic polymorphism have not been undertaken in the $C$ pipiens Group of South Americ

This paper presents a study of the distribution of allele frequencies for seven polymorphic enzym loci in six populations of $C x$. pipiens and $C x$. quinquefasciatus from Argentina, situated along north-south line of about $2,000 \mathrm{~km}$, and an estimation of the degree of gene flow and genetic divergence among them. Crossing experiments between mosquitoes from the two extreme populations of this line were also performed.

\section{MATERIALS AND METHODS}

Samples were taken from the following localities (Fig. 1): Castelli, 255' $\mathrm{S}$ (Chaco Province) Esperanza, $31^{\circ} 26^{\prime} \mathrm{S}$ and Rosario, $32^{\circ} 56^{\prime} \mathrm{S}$ (Santa 38 $38^{\circ}$ 'S (Buenos Aires Province) and Puerto

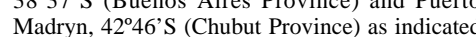
Madryn, 42 46'S (Chubut Province) as indicated in Almiron et al. (1995). These localites are situa subtropical region with a mect, the area includes ture of $25^{\circ} \mathrm{C}$ in the noth a most section, while southern limit presents an average anual temperature of $10^{\circ} \mathrm{C}$.

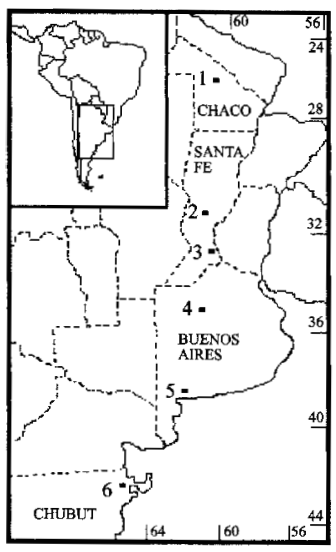

Fig. 1: location of Culex pipiens and Cx. quinquefasciatus col-
lection sites. 1. Castelli: 2: Esperanza: $3:$ Rosario $4 \cdot 9$ de Julio lection sites. 1: Castelli, 2: Esperanz:
5: Bahía Blanca; 6: Puerto Madryn.
Females were collected from natural resting sites using baited (chicken) can traps, and then transported alived to the laboratory. In order to obtain egg rafts, the field females were placed individually in plastic tubes with wet cotton and filter paper at the bottom. The egg rafts were reared as individual progenies in plastic trays $\left(25^{\circ} \pm 3^{\circ} \mathrm{C}\right.$ 14:10 L/D photoperiod). Larvae were fed with commercial rodent food until adults emerged. Adults were frozen at $-40^{\circ} \mathrm{C}, 48 \mathrm{hr}$ after emergence, until electrophoresis was performed. Five to seven males from each progeny were examined for phallosome morphology and morphometry (DV/D ratio) (Sundararaman 1949).

Electrophoretic analysis - Homogenates were obtained from single individuals crushed in distilled water. The resulting suspension was absorbe in a Whatman $3 \mathrm{MM}$ paper wick $(2.5 \mathrm{~mm})$ an inserted in starch gel trays. Homogenates from six to nine descendants of each progeny were place in a gel block which admitted up to sixteen insertions. The number of families analyzed from each locality are indicated in Table I. Standard horizontal electrophoresis was carried out at $4^{\circ} \mathrm{C}$. Gels were sliced longitudinally into four slabs and each one tained for specific enzymes (Humeres et al. 1990). The following buffer systems were used: continuous Tris-boric EDTA, pH: 8.6 (Markert \& Faulhaber 1965), for the separation of catalases (CAT), glycerophosphate dehydrogenase (GPDH) 6.7 for 6.7 for gels and $\mathrm{pH}$ : 6.3 for the electrode cells (Shows \& Rudde 1968) for malate (MDH) an lithirate (IDH) de $\mathrm{pH}$.4 (Steiner \& Joly 1979) phate isomerase (GPI).

Alleles were assigned a number according to the relative wering 100 a index of genetic disten (D) proposed by Neic (1972) was used to estimate the degree of divergence between populations. The analysis was performed using the Genind program (Vilard 1992). Gene flow was estimated using Wright's (1965) F-statistics as modified by Nei and Chesse (1983). Effective migration rate (Nm) was calculated from $\mathrm{F}_{\mathrm{ST}}$

Crossing experiments - The following crosses were performed as indicated in Almirón et al. (1995): females Cx. pipiens (Puerto Madryn) x males $C x$ quinquefasciatus (Castelli) and its reciprocal.

\section{RESULTS}

According to the analysis of male genitalia Cx. quinquefasciatus was exclusively present i

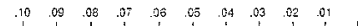

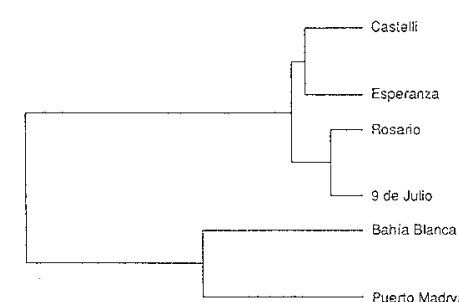

Fig. 2: phenogram constructed using the unweighted pair group

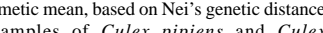
values among
quinquefasciatus.

the northern localities of Castelli and Esperanza. In Rosario, although $C x$. quinquefasciatus waspredominant, hybrids were also detected. Almost all individuals from the 9 de Julio sample belonged to $C x$. pipiens except one $C x$. quinquefasciatus. In the southern localities (Bahía Blanca and Puerto Madryn), only Cx. pipiens (Almirón et al. 1995) has been identified.

Electrophoretic analysis - Zymograms obtained allowed the analysis of seven loci: $\mathrm{Cat}, \mathrm{Mdh}, \mathrm{Idh}$, Gpdh, Hk-1, Pgm, and Gpi. Criteria of genetic interpretation was similar to those applied by other authors to polymorphisms detected in different mosquito species (Steiner \& Joslyn 1979, Villani

Parental genotypes for each isofemale line were determined when unequivocal, and allelic frequenTable I. In all cases, genotypes were distributed according to the Hardy-Weinberg equilibrium. The predominant alleles at the $M d h, I d h, G p d h$ and $G p i$ loci presented similar frequencies in all samples. For the $P$ gm locus, allele 93 was predont in Co most frequent in Bahí Blanca and Puerto Madryn. The intermediate localities of Rosario and 9 de Julio presented similar frequencies. Allelic frequencies of $C a t$ and $H k-l$ differ markedly between extreme populations. $H k-l$ shows a striking latitudinal cline. Values of Nei's genetic distance between the populations are presented in Table II. Samples including typical Cx. pipiens (Bahía Blanca, 9 de Julio and Puerto Madryn) show a low genetic distance. Samples from the localities of Castelli, Esperanza and Rosario, where $C x$. quinquefasciatus was predominant, were also genetically homogeneous. However, 9 de Julio and Rosario samples showed the lowest value of genetic distance $\left(D_{\mathrm{N}}=0.011\right)$, although they were
TABLE

Allelic frequencies of polymorphic loci in six quinquefasciatus from Arge Cur

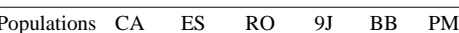
Locus Allele

$\begin{array}{llllllll}\text { Cat } & 100 & 0.22 & 0.28 & 0.42 & 0.26 & 0.26 & 0.62\end{array}$ $\begin{array}{lllllll}43 & 0.78 & 0.72 & 0.58 & 0.74 & 0.74 & 0.38\end{array}$

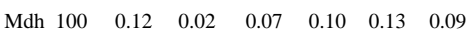
$\begin{array}{lllllll}83 & 0.88 & 0.98 & 0.93 & 0.90 & 0.87 & 0.90\end{array}$ $\begin{array}{lllllll}63 & 0.00 & 0.00 & 0.00 & 0.00 & 0.00 & 0.01\end{array}$

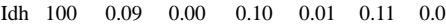
$\begin{array}{lllllll}90 & 0.91 & 1.00 & 0.89 & 0.96 & 0.88 & 0.93\end{array}$ $\begin{array}{lllllll}80 & 0.00 & 0.00 & 0.01 & 0.03 & 0.01 & 0.02\end{array}$ $\begin{array}{lllllll}\text { Gpdh } 100 & 0.00 & 0.00 & 0.00 & 0.06 & 0.01 & 0.00\end{array}$ $\begin{array}{lllllll}79 & 0.20 & 0.05 & 0.24 & 0.06 & 0.25 & 0.06\end{array}$ $\begin{array}{lllllll}71 & 0.73 & 0.87 & 0.73 & 0.79 & 0.73 & 0.90\end{array}$ $\begin{array}{lllllll}59 & 0.07 & 0.08 & 0.03 & 0.08 & 0.01 & 0.04\end{array}$

$\begin{array}{llllllll}40 & 0.00 & 0.00 & 0.00 & 0.01 & 0.00 & 0.00\end{array}$

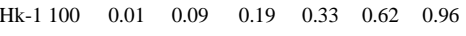
$\begin{array}{lllllll}90 & 0.99 & 0.91 & 0.81 & 0.67 & 0.38 & 0.04\end{array}$ $\begin{array}{llllllll}\text { Pom } 100 & 0.47 & 0.42 & 0.29 & 0.25 & 0.53 & 0.55\end{array}$ $\begin{array}{lllllll}93 & 0.53 & 0.58 & 0.64 & 0.75 & 0.47 & 0.45\end{array}$ $\begin{array}{lllllll}83 & 0.00 & 0.00 & 0.07 & 0.00 & 0.00 & 0.00\end{array}$ $\begin{array}{lllllll}\text { Gpi } 100 & 0.06 & 0.00 & 0.01 & 0.00 & 0.04 & 0.06\end{array}$ \begin{tabular}{lllllll}
94 & 0.94 & 1.00 & 0.99 & 1.00 & 0.96 & 0.94 \\
\hline
\end{tabular}

$\begin{array}{lllllll}\text { families } 4 & 5 & 31 & 46 & 37 & 42 & 30\end{array}$ CA: Castelli (Chaco Province); ES: Esperanza and RO: Rosario (Santa Fe Province); 9J: 9 de Julio and BB: Bahh (Chubut Province).

TABLE II

Values of genetic distance -D- in six populations of Culex pipiens and Culex quinquefasciatus from Argentina

\begin{tabular}{lcccccc}
\hline \multicolumn{6}{c}{ D } \\
\hline & CA & ES & RO & 9J & BB & PM \\
\hline CA & 0.019 & 0.015 & 0.028 & 0.072 & 0.225 \\
ES & & 0.024 & 0.027 & 0.076 & 0.187 \\
RO & & & & 0.011 & 0.050 & 0.144 \\
9J & & & & & 0.033 & 0.120 \\
BB & & & & & & 0.049
\end{tabular}

A: Castelli (Chaco Province); ES: Esperanza and RO: Rosario (Santa Fe Province); $9 \mathrm{~J}$ : 9 de Julio and BB: Bah' Blanca (Buenos Aires Province); PM: Puerto Madryn (Chubut Province). 
represented almost exclusively by $C x$. pipiens and from extreme sites of the study are presented the highest value of genetic distance $(\mathrm{D}=0.225$ ). Fig. 2 summarizes these data in a dendrogrm based on $D$ values and clustered using the Genind program. A significant correlation between genetic an geographical distances was detected $(r=0.83$; $<0.001)$. In Table III, $\mathrm{F}_{\mathrm{ST}}$ and $\mathrm{Nm}$ values are presented for the analyzed loci in the six populations.

TABLE III

Values of $\mathrm{F}_{\mathrm{ST}}$ and $\mathrm{Nm}$ in seven loci analyzed from populations of Culex pipiens and $\mathrm{Cul}$ quinquefasciatus from Argentina

\begin{tabular}{llr}
\hline Locus & \multicolumn{1}{c}{$\mathrm{F}_{\mathrm{ST}}$} & \multicolumn{1}{c}{$\mathrm{Nm}$} \\
\hline Cat & $0.08387^{a}$ & 2.73 \\
Mdh & 0.00663 & 37.45 \\
Idh & 0.01852 & 13.24 \\
Gpdh & 0.03147 & 7.69 \\
Hk-1 & $0.46009^{b}$ & 0.29 \\
Pgm & 0.01680 & 14.60 \\
Gpi & 0.00071 & 351.86 \\
$\overline{\mathrm{X}}$ & 0.088 & 61.12 \\
$\overline{\mathrm{X}}^{\mathrm{a}}$ & 0.026 & 71.26 \\
\hline$a: \mathrm{p}<0.05 ; b: \mathrm{p}<0.001 ; \overline{\mathrm{X}}$ : mean; $\overline{\mathrm{X}}^{\mathrm{a}}$ : mean excluding
\end{tabular}
$a: \mathrm{p}<0$.
Hk-1

Crossing experiments - Viable eggs were obtained from both crosses. Crosses involving female $C x$. pipiens from Puerto Madryn $\mathrm{x}$ male $C x$. quinquefasciatus from Castelli showed hatchin
rates of $100 \%$, and $76.5 \%$ in the reciprocal. The $\mathrm{F}_{1}$ and $\mathrm{F}_{2}$ offspring of both crosses proved to be fertile, with hatching rates between 95 and $100 \%$ (Table IV). The colony was discarded after obtaining the $\mathrm{F}_{3}$

TABLE IV

Results of crosses between Culex pipiens (Cx.p.) and Culex quinquefasciatus (Cx.q.) from Castelli, CA (Chaco Province) and Puerto Madryn, PM (Chubut Province)

\begin{tabular}{|c|c|c|c|c|c|c|c|c|c|}
\hline \multirow{3}{*}{\multicolumn{2}{|c|}{ Crosses }} & \multicolumn{2}{|c|}{$\mathrm{N}$} & \multicolumn{2}{|c|}{$\mathrm{F}_{1}$} & \multirow{2}{*}{\multicolumn{2}{|c|}{$\frac{\mathrm{F}_{1} \times \mathrm{F}_{1}}{\text { Egg rafts }}$}} & \multirow{2}{*}{\multicolumn{2}{|c|}{$\frac{\mathrm{F}_{2} \times \mathrm{F}_{2}}{\text { Egg rafts }}$}} \\
\hline & & \multirow[t]{2}{*}{ Female } & \multirow[t]{2}{*}{ Male } & \multirow{2}{*}{\multicolumn{2}{|c|}{$\begin{array}{l}\text { Egg rafts } \\
\text { Obt. } \quad \text { Hatched }\end{array}$}} & & & & \\
\hline & & & & & & \multicolumn{2}{|c|}{$\begin{array}{l}\text { Egg rafts } \\
\text { Obt. Hatched }\end{array}$} & \multicolumn{2}{|c|}{\begin{tabular}{l}
\multicolumn{2}{c}{ Egg rafts } \\
Obt. Hatched
\end{tabular}} \\
\hline $\begin{array}{l}\text { Female } \\
\text { Cx.p. } \quad \mathrm{x} \\
\text { PM }\end{array}$ & $\begin{array}{l}\text { Male } \\
\text { Cx.q. } \\
\text { CA }\end{array}$ & 102 & 196 & 36 & 100 & 43 & 100 & 9 & 95 \\
\hline $\begin{array}{l}\text { Female } \\
\text { Cx.q. } \quad \mathrm{x} \\
\text { CA }\end{array}$ & $\begin{array}{l}\text { Male } \\
\text { Cx.p. } \\
\text { PM. }\end{array}$ & 84 & 111 & 17 & 76.5 & 31 & 100 & 40 & 100 \\
\hline
\end{tabular}

Geographic patterns of allele frequencies in $C x$. pipiens and $C x$. quinquefasciatus were analyzed fo populations from different collection sites in an exwhere $C x$ quinquefasciatus was found nsperanza fect with the St. Louis encephalitis virus (Mitchell et al. 1985). Although allele frequencies at one of the seven loci analyzed $(H k-l)$ showed marked clinal gradient across the studied area (Table the loci did not allow the characterization of $C$ pipiens and $C x$ quinquefasciatus. Similar results were obtained by Cheng et al (1982) and Tabachnick and Powell (1983)

Hexokinase $(H k-1)$, 6-phosphogluconate dehy-
rogenase $(6 P g d h)$, glucosephosphate isomerase (Gpi) and phosphoglucomutase (Pgm), exhibit laticudinal cline in gene frequencies across the range of the species in the United States (Cheng et al. the same loci tick and Powell (1983) reported that gradient in the Central Valley of California. In our study, a similar pattern was found only for locu $H \mathrm{k}-1$, with a frequency for allele 100 ranging from 0.01 in the northernmost point of the sampling area to 0.96 in the southernmost collection site (Table I) ignated $\mathrm{Hk}_{\mathrm{A}}$ and $\mathrm{Hk}_{\mathrm{B}}$ by Cheng et al. (1982) for populations from North America, where $\mathrm{Hk}_{\mathrm{A}}$ de

Allele frequencies at $P g m$ locus did not correlation with DV/D ratios, as demonstrated by (1983). These alleles presented a particular distribution (Table I), being similar for populations from the warm and cold areas (Pgm 93: 0.53 and 0.58 for Castelli and Esperanza; 0.47 and 0.45 for Bahí Blanca and Puerto Madryn) and between the two termediate ones (Pgm 93: 0.64 and 0.75 for
Rosario and 9 de Julio). Population pairs with similar allele frequencies, share similar environmental conditions (not only temperature), since they occupy approximately the same geographic area. This may produce a non random distribution of genetic variants.

An unique allele $(c)$ for the Pgm locus was found in the sample from Rosario with a frequency of 7\%. In this site, hybrid specimens (according to the DV/D ratio) were detected in a proportion of 4.7\% (Almirón et al. 1995). The presence of rare alleles in hybrid populations has been reported for different animal groups; intragenic recombination was proposed to explain it (Golding \& Strobeck were allele was confined to the hybrid specimens.

Estimation of the standardized variance in genic frequencies among populations $\left(\mathrm{F}_{\mathrm{ST}}\right)$ gave an average value of 0.088 , and an average $N m$ of 61.12 flow is cording to Wrigh (1978). Howeve, if $H / 2-1$ is excluded, these values are 0.026 and 7126 respectively. As it has already been pointed out different alleles at the $H k-l$ locus are present in high frecencion 1 90: 0.99 in Castelli and 0.04 in Puerto Madryn: $\left.\mathrm{F}_{\mathrm{ST}}=0.46, \mathrm{p}<0.0001\right)$ suggesting that natural selection at this locus is strong enough in preventing gene flow to homogenyze gene frequencies. Pryor (1980) demonstrated differential heat stability of different allele products at $H k$ - $I$ locus, being the heatstable ones more common in $C x$. quinquefasciatus. This finding would indicate that temperature could be an important factor determining genetic composition of populations at $H k-l$ locus. Although in a lower degree, the locus $\mathrm{Cat}$ also showed significant ocal differentiation $\left(\mathrm{F}_{\mathrm{ST}}=0.08, \mathrm{p}<0.05\right)$, but there was no correlation with the sample origin.

Another approach to understand patterns of geographic variation is the analysis of genetic distance values among populations. The lowest distance (Table III) correspond to the geographically suggesting that $C x$ pipiens and $\mathrm{D}_{\mathrm{N}}=0.01$ ) arefasciutus are aste queasciaus are a stable interbreeding unit in

On the other hand, a good cor

genetic and geographical distance $(r=0.83 ; p<$ 0.001 ) was found. It is difficult to explain this observation as produced by a drift-migration interaction, taking into account the $\mathrm{F}$ values for different loci. It could be assumed that this correlation would be mainly determined by loci under the control of natural selection, being temperature an important selective factor for the maintenance of genetic cohesion among populations of the same species.

The average value of $\mathrm{D}$ was 0.102 , lower than hat reported by Urbanelli et al. (1985) between from Africa $(\mathrm{D}=0.145)$. $\mathrm{D}$ values ranging from 0.05 to 0.2 are considered to correspond to popuations of the same species (Ayala 1975).

Almirón et al. (1995) performed different crosses between $C x$. pipiens and $C x$. quinquefasciatus from a central area of Argentina including three localities Bahía Blanca, Buenos Aires Province; Córdoba, Cordoba Province; and Rosario, Santa Fe Province). Corching from 70 to $100 \%$ was reported by those pipiens except for one cross involving female $C x$. pipiens from Bahía Blanca $x$ male $C x$. quinquefasciatus from Rosario, where a high incompat-

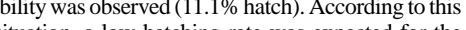
costion, a low hatching rate was expected for the x male $C x$ quinquefasciatus from Castelli, which ot happen (Table IV). An inom Castelli, which did gent of the genu Wolbachia found in ticketsial issues of arthropods (including $C x$. pipiens) been reported as having a profound effect on the host's perm from a WolbachiaPected male fertilizes an uninfected egg, unidirecional cytoplasmic incompatibility can occur producing zygotic death. Different factors as bacterial strain, host genotype and bacterial density seems to influence strength and direction of that incompatibility Werren 1997). In our case, Castelli and Puerto Madryn populations showed the highest genetic disance; however, 76.5 to $100 \%$ of hatching was re-

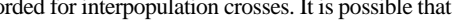
Wopulion from Rosario was infected by a Wolbachia strain not present in other populations Wested. This may explain the important unidirectional

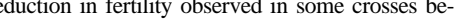

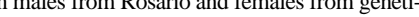
cally similar populations.

The finding of hybrid individuals in samples from Córdoba and Rosario, and the fertility of the hybrids obtained under laboratory conditions on provide enetic evidence about the subsecific us of $C x$. pipiens and $C x$. quinquefasciatus in $A-$ The recognition of the existence of an important gene flow between intermediate populations of both forms provides useful information on heir dispersal potential, and possibly of the infectious agent they transmit. This knowledge may also afford data for any attempt to perform genetic control on the species.

\section{ACKNOWLEDGMENT}

To Dr Antonio Blanco for the critical revision of the manuscript; to Dr Thomas P Monath, who kindly sup-

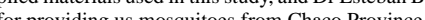




\section{REFERENCES}

Almirón WR, Humeres SG, Gardenal CN 1995. Distribution and hybridization between Culex pipiens an entina. Mem Inst Oswaldo Cruz 90: 469-473. ala FJ 1975. Genetic differentiation during the speciation process. Evol Biol 8: 1-78.

Barr AR 1957. The distribution of Culex pipiens pipien and Culex pipiens quinquefasciatus in Nort Barr AR 1982. The Culex pipiens complex, p. $551-572$
In WWM Steiner, WJ Tabachnick, KS Rai, S Narang (eds), Recent Developments in the Genetics of Insect Disease Vectors, Champaign, Illinois, Stipes.

Bekku H 1956. Studies on the Culex pipiens group of Japan. I. Comparative studies on the morphology o Neseraki Med J3: $956-966$. ewer M, Buffa L, Almirón W

W 1987. Culex pipiens quinquefasciatus y Culex pipiens pipiens (Diptera
Culicidae) en Córdoba, Argentina. Rev Per Entomol

29: 69-72.
Cheng ML 1976. Genetic variability in the comple Culex pipiens (Diptera: Culicidae), Ph.D. thesi Cheng ML, Hacker CS, Pryo

or SC, Ferrel RE, Kitto GB complex in North America, p. 581-627. In WWM Steiner, WJ Tabachnick, KS Rai, S Narang (eds), Recent Developments in the Genetics of Insect Disease Vectors, Champaign, Hinois, Stipes.

pipiens complex in the South Pacific (the Culex Australia). Bull WHO 37: 251-255.

Donaldson JMI 1979. The Culex pipiens complex in South Africa. $J$ Entomol Soc Sth Afr 42: 35-50.

Edwards FW 1921. A revision of the mosquitoes of the Palaearctic Region. Bull Entomol Res 12. 263-351. leles found in hybrid populations due to intragenic recombination. Evol 37: 17-29.

Harbach RE 1985. Pictorial keys to the genera of mo quitoes, subgenera of Culex and the species of Culex. Culex) occurring in southwestern Asia and Egyp, with a note on the subgeneric placement of Culex

Harbach RE 1988. The mosquitoes of the subgenus Culex in Southwestern Asia and Egypt (Diptera: Culicidae). Contrib Am Entomol Inst 24: 1-240.

Humeres SG, Gardenal GN, Almirón WR, Sereno R, Sabattini MS 1990. Culex species (Diptera: CulCophortic zy mog Age and genetic relationships. $J$ Med Ent 27: 784-788.

shii T 1980. On the Culex pipiens group in Japan. Part III. A historical review of its research. $J$ Sci Coll

Jakob WL, Taylor SA, Francy DB 1980. Additional stud. Mosq Syst 12: 386-391 Culex) quinquefasciatus Say in South Africa: mo hological and reproductive evidence in favour of their status as two species. Mosq Syst 10:461-473. aven H 1967. Speciation and evolution in Culex pipiens, p. 251-275. In JW Wright \& R Pal (eds), Genetics of
Insect Vectors of Disease, Elsevier, North Holland, Amsterdam. Amsterdam.
Markert CL, Faulhaber I 1965. Lactate dehydrogenase isozyme patterns of fish. J Exp Zool 159: 319-332. attingly PF 1951. The Culex pipiens complex. Tran $R$ Entomol Soc (Lond) 102: 331-342.

Mitchell JC, Monath TP, Sabattini MS 1980. Transmission of St. Louis encephalitis virus from Argentina by mosquitoes of the Culex pipiens (Diptera: Culi-

Mitchell JC, Monath TP, Sabattini MS, Cropp C, Daffne Calisher C, Chentina. II. Arthropod collections an virus isolations from mosquitoes, 1977-1980. Am J Trop Med Hyg 34: 945-955.

Nei M 1972. Genetic distance between populations. $A m$ Nat 106: 238-292.

and gene diversities. Ann Hum Genet 47: 253-259.
and yor SC 1980. Biochemical genetics of the Culex pipiens complex. II. Hexokinase. Comp Biochem Physiol B Comp Biochem 67: 705-710.

asa M, Kanda T, Miura A, Yamaguti N 1963. Biological and taxonomical studies on some colonies of Culex pipiens s.l., from eastern and southern Japan. Jap J Exp Med 33: 1-31.

Shows TB, Ruddle FH 1968. Malate dehydrogenase evidence for tetrameric structure in Mus musculus. Science 160: 1356-1357. nique for the genetic study
News 39: $35-53$.

undararaman S 1949. Biometrical studies on intergradation in the genitalia of certain populations of Culex pipiens and Culex quinquefasciatus in Nort America. Am J Top Med Hyg 6. 153-165.

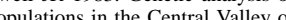
California. Ann Entomol Soc Am 76: 715-720.

rbanelli S, Bullini L, Villani F 1985. Electrophoretic studies on Culex quinquefasciatus Say from Africa: genetic variability and divergence from Culex pipiens

Villani F, Urbanelli S, Gad A, Nuddman S, Bullini L 1986. Electrophoretic variation of Culex pipiens from Egypt and Israel. Biol J Linn Soc 29: 49-62.

índices de distancia y variabilidad genética y su errores a partir de muestras pequeñas. Mendeliana 10. 1 -

Werren JH 1997. Biology of Wolbachia. Annu Re Entomol 42: 587-609.
right S 1965. The inter

ture by F-statistics with special regard to system of mating. Evolution 19: 395-420.

right S 1978. Evolution and the Genetics of Populations, Vol 4. Variability within and among Natura $565 \mathrm{pp}$. 